\title{
The Training Performance Of Sub Elit Adolescent Archery Athletes Before And During Covid-19 Pandemic
}

\author{
Fani Ravena ${ }^{1}$, Ajeng Sindi Tirtasari ${ }^{2}$, Irmantara Subagio $^{3}$, Azizati Rochmania ${ }^{4}$, Kunjung \\ Ashadi $^{5}$ \\ \{fani.17060474140@mhs.unesa.ac.id ${ }^{1}$, ajeng.17060474139@mhs.unesa.ac.id ${ }^{2}$, \\ irmantarasubagio@unesa.ac.id $\left.{ }^{3}\right\}$ \\ Universitas Negeri Surabaya, Surabaya, Indonesia ${ }^{1,2,3}$
}

\begin{abstract}
The purpose of this study was to know training performa sub elite adolescent archery athletes at the Center for Education and Training for Student Sports (PPLP) before and during covid-19 pandemic. The method used descriptive quantitative. The subject is six female and three male adolescent archery athletes with maximum age is 18 years old. The instrument used push-up test during one minutes to measure arm muscle endurance, a scoring test to measure target accuracy and measure athletes pulse one minutes to find out the ratio of pulse rate during training. Data analysis techniques used are the mean, standard deviation, percentage and normality test, and Paired Sample T Test. The study's conclusion from the results showed no significant difference in the endurance of the athlete's arm muscles $(\mathrm{P}>0,05)$, while there is a significant difference in target accuracy and athlete's pulse $(\mathrm{P}<0,05)$ before and during covid-19 pandemic.
\end{abstract}

Keywords: Arm muscle endurance, target accuracy, pulse, athlete, archery.

\section{Introduction}

Various sports have made quite high achievements by winning various events majorin the World. One of the sports that is currently in demand is archery, which is a shooting skill with a bow and arrow. Meanwhile, archery is a skill or art by shooting arrows using a bow [1] .

According to Munawar et al [2] Arm muscle endurance strength is one of the factors that influence archery sport achievement which is an important part of athlete's performance in a competition. Archery can be interpreted as a sports activity of targeting accuracy because with the correct archery technique and the regularity of shooting arrows at the target as precisely as possible [3] . Archery is competed from the national to international level with various divisions, namely:division standard bow, recurve, and compound. The distances contested are also different, for thedivision the standard bow distance is 30-50 meters, thedivision is recurve 6090 meters, thedivision is compound distance 50 meters [4] . In order for archery athletes to get good and consistent results, physical condition and level of flexibility, coordination, balance and endurance are needed [2] .

At the time of lifting the bow, pulling the bowstring, aiming at the target and releasing the arrow, it really requires maximum arm muscle endurance so that the arrow is right on the right target and gets high points [5]. By looking at the current situation we are facing, there is the impact of Covid-19 which is very detrimental to all of us, even there are many athletes whose 
physical condition has decreased, one of which is an archery athlete who is not strong enough to pull the last encroachment and lose balance while aiming at the target so that they do not get results score maximum. In the archery sport, an athlete is required to get score a highby having good skills and techniques that will help in aiming at the target with the right target [6] .

According to Akbar et al [7] Lack of physical exercise and exercise will result in the influence of adrenergic hormones in the heart to be more dominant so that it can increase the pulse rate. Regular exercise will result in less adrenergic hormone activity while resting, which will lower the pulse rate in people who have regular exercise and physical exercise habits, so that the heart becomes more effective in pumping blood throughout the body. The decline in sports activities during the Covid-19 pandemic in sports students and an increase in sports activity patterns among non-sports students were the most prominent things. The purpose of this change was made by students to maintain immunity during the Covid-19 pandemic [8] .

Other research states that tablets must always maintain immunity before, during and after exercise [9] . Bashri et al [10] in their research showed that educational media was very feasible based on the results of expert validation and user responses, especially the elderly. Prevention of covid-19 transmission and a healthy lifestyle for the elderly with herbal drinks developed through videos and e-flyers is one of the products of this educational media.

All people are encouraged to carry out regular physical activity during the Covid-19 outbreak as an effort to maintain immunity [11]. Similar research states that students have decreased physical activity during the Covid-19 pandemic. Therefore, it is highly recommended to do sports based on frequency, intensity, time and type with a duration of 150 [12] .

Therefore, it is necessary to carry out this study to determine how much the ratio of muscle endurance, archery target accuracy and athlete's pulse training in the pre-Covid period with the current situation. So that athletes can improve their performance and coaches can understand and pay attention to the training in progress. For this reason, it is very important to carry out this research in order to obtain actual data.

\section{Method}

The type of research approach is descriptive quantitative. This research design used a oneshoot study where the data collection only took place once a day. The target of this study used 9 athletes as the subject, with details of 6 female athletes and 3 male athletes from three divisions of Standard Bow, Recurve and Compund who are PPLP Panahn East Java athletes who live in Surabaya. In this study, researchers will do atest push-up to measure the endurance of the arm muscles, atest scoring to measure target accuracy and then a test to calculate the athlete's pulse to measure how much the pulse issued by PPLP Archery athletes of East Java. Data analysis techniques used mean, standard deviation, percentage, normality, and different tests using the Paired Sample T Test with the IBM SPSS version 24 and Microsoft Excel version 2010 analysis tools.

\section{Results}

Based on the results of data analysis carried out using push-up tests, scoring tests and pulse counting tests for PPLP Archery athletes in East Java, the following profiles were obtained. 
According to Diagram 1 in this study using 9 samples of East Java PPLP athletes consisting of 3 male athletes and 6 female athletes.

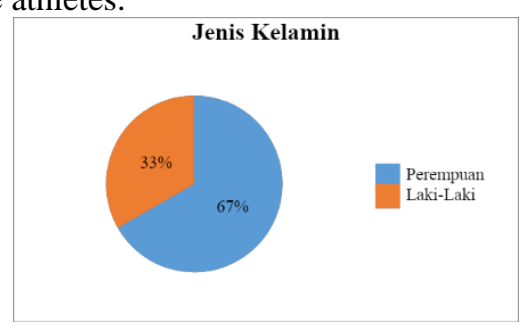

Fig. 1. Gender of subjects research

From diagram 1, it can be seen that the East Java PPLP Panahan athletes consisted of 33.33\% male and $66.67 \%$ female athletes. Which means the number of athletes is 9 and consists of 3 male athletes and 6 female athletes.

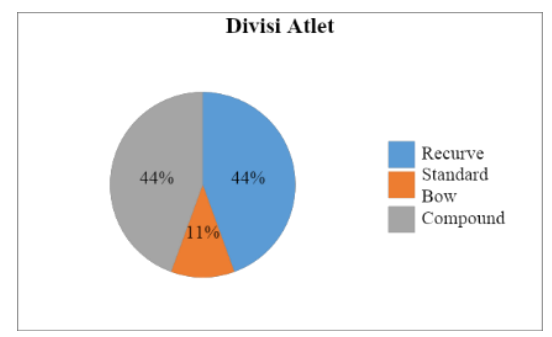

Fig. 2. Division of subject athletes research

From diagram 2 it can be seen that the PPLP Archery athletes of East Java, consist of 44.44\%division recurve, $44.44 \%$ compound and $11.11 \%$ division standard bow. Which means the number of athletes is 9 and consists of 4athletes recurve, 4athletes compound and 1athlete standard bow.

To find out the average value of arm muscle endurance, the accuracy of archery targets and the athlete's pulse in the period before Covid-19 and during the COVID-19 pandemic, athletes were tested with the Paired Sample T Test, which was obliged to perform a normality test first. Following are the results of data normality testing using Kolmogorov Smirnov and Shapiro Wilk which can be presented in table 1 .

Table 1. Test normality

\begin{tabular}{lcrrr}
\hline & \multicolumn{2}{c}{ Kolmogorov-Smirnova } & \multicolumn{2}{c}{ Shapiro-Wilk } \\
& Sig. & Description & Sig. & Description \\
\hline Normal_Otot & $.200^{*}$ & Normal & .936 & Normal \\
Normal_Accuracy & $.200^{*}$ & Normal & .812 & Normal \\
Normal_Deat & $.200^{*}$ & Normal & .821 & Normal \\
\hline
\end{tabular}


Based on table 1, it is known that the Kolmogorov-Smirnov significance value Sig. from arm muscle endurance (0.200), archery target accuracy (0.200) and the Covid-19 Pandemic pulse rate $(0.200)$, each of which is $>0.05$, which means that the normality test uses the Kolmogorov Smirnov data normally distributed. In addition to testing for normality using Kolmogorov, Smirnov can also test with Shapiro-Wilk with a Sig value. Arm muscle endurance (0.936), archery target accuracy (0.812) and the Covid-19 Pandemic pulse rate (0.821), each of which value is $>0.05$, it can be concluded that the data is normally distributed, which means that the normality requirements in the regression model are met. After the requirements are met, to calculate the average value of the comparative level of arm muscle endurance, the accuracy of archery targets and the pulse of the Covid-19 Pandemic athletes in the period before Covid-19 and during the Covid-19 pandemic, the difference can be calculated using the Paired Sample T Test. in Table 2.

Table 2. Muscle descriptive test

\begin{tabular}{lllr}
\hline & & Mean & \multicolumn{1}{c}{ Std. Deviation } \\
\hline Pair 1 & Pre_Otot & 32.3333 & 4.63681 \\
& Post_Otot & 31.1111 & 10.62361 \\
\hline
\end{tabular}

In the results of Table 2, a summary of the descriptive results of the two data categories studied was obtained, namely the variables Before Covid-19 (Pre_Otot) and the Pandemic Situation (Post_Otot). For the Pre_Otot value, the mean Arm Muscle Endurance is 32.3333. As for the Post_Otot value, the mean value of Arm Muscle Endurance is obtained at 31.1111. The number of East Java Archery PPLP athletes used as respondents was 9 athletes.

Based on Diagram 3, it can be seen that the average ratio of values on muscle endurance was higher before the pandemic, this is because before the pandemic athletes received longer and more intensive training than during the pandemic. For more details, it can be seen in Figure 3 as follows.

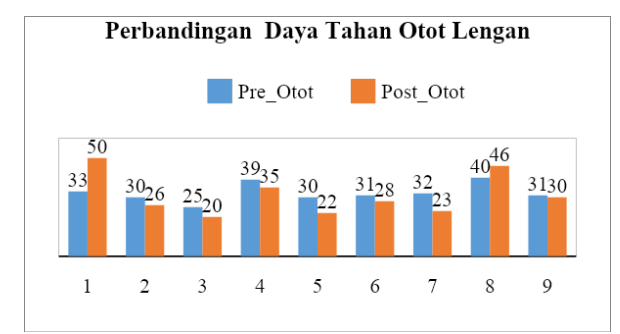

Fig. 3. Diagram difference avg arm muscle endurance athletes archery PPLP East Java in the prior Covid-19 with pandemic situations Covid-19

Results mean arm muscle endurance in Before Pandemic 32.3333<Masa pandemic 31.1111, concluded there is a difference Mean Arm Muscle Endurance between Before and Moderate pandemic results. Then the $t$ test difference test was carried out to analyze the significant differences between the two data which are found in Table 4 Paired Samples Test. Also obtained the results of the average difference value of -0.800 , which means that there is a difference 
between the average Pre_Otot Arm Muscle Endurance and the average Post_Otot Arm Muscle Endurance or $32.333-31.1111=1.22222$.

Table 3 shows the results of the correlation value between the pre-pandemic variable and the moderate pandemic variable. For more details, it can be seen in Table 3 as follows.

Table 3. Muscle correlation test

\begin{tabular}{lrrrcc}
\hline & & N & Correlation & Sig. & Information for \\
\hline Pair 1 & Pre_Otot \& Post_Otot & 9 & .700 & .036 & There is a difference. \\
\hline
\end{tabular}

Based on table 3, the Correlation value is 0.700 with a significant value of Sig. $0.036<0.05$ probability means that there is a relationship between before the pandemic and the moderate pandemic variable. The results of table 4 show that there is a difference in the average difference in Arm Muscle Endurance before and during the Covid-19 Pandemic, the Sig value can be seen. (2-tailed) of 0.662>0.05, which means there is no difference in the mean Arm Muscle Endurance before and during the Covid-19 Pandemic.

Table 4. Different t-T- test muscle test

\begin{tabular}{cccc}
\hline & & Sig. (2-tailed) & Description \\
\hline Pair 1 & Pre_Otot - Post_Otot & .662 & Not Significant \\
\hline
\end{tabular}

Based on the average data calculation, the calculation of Arm Muscle Endurance before the Covid-19 Pandemic was 32.333, which means the average value of the athlete's Arm Muscle Endurance category. before the Covid-19 Pandemic was in a higher category than when the Covid-19 Pandemic got 31.1111 results, which means that the average value of the Arm Muscle Endurance category for athletes in the Covid-19 Pandemic situation was in a smaller category. And after using the Paired T Test, the results showed that there was a significant difference between Arm Muscle Endurance before the Covid-19 Pandemic and during the pandemic.

Based on Diagram 4, it can be seen that the average value comparison on target accuracy was higher before the pandemic, this happened because before the pandemic athletes received a more intensive training schedule than during the pandemic. For more details, it can be seen in Figure 5 as follows.

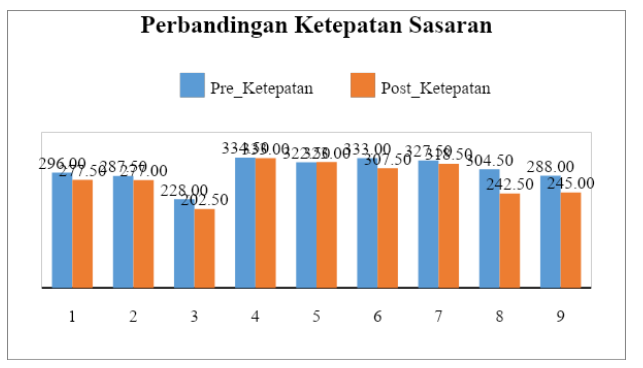


Fig. 4. Diagram of the difference in average target accuracy of athletes in the pre-Covid-19 period with the Covid-19 pandemic situation

In the results of Table 5, a summary of the descriptive results of two variables of the accuracy of targeting archery athletes is obtained, namely before the pandemic (pre-precision) and moderate pandemic (post_accuracy). For the Pre_accuracy value, the mean Target Accuracy is 302.3889. Meanwhile, for the Post-precision value, a mean of 280.7222 was obtained. The number of East Java Archery PPLP athletes used as respondents was 9 athletes.

Table 5. Descriptive test of accuracy of

\begin{tabular}{llcr}
\hline & & Mean & Std. Deviation \\
\hline Pair 1 & Pre_Ceteness & 302.3889 & 33.56130 \\
& Post_Ketoritas & 280.7222 & 44.08026 \\
\hline
\end{tabular}

Based on Table 5, the results of the mean Target Accuracy at Pre_accuracy 302.3889 <Post_quality 280.7222 mean that there is a difference in mean Target Accuracy between Pre_accuracy and Post_accuracy results. Also obtained the results of the average difference value -21.66667. Which of these results shows the difference between the average Pre_Correctness and the average Post Test Target Accuracy or 302.3889 - 280.7222=21.66667 with the difference between 6.04430 to 37.28903 . With the information t count has a positive value of 3.198, which means that the mean value of Pre_Ceteness $>$ than the mean Post_Cetness.

The next step after calculating the average comparison is seeing the value relationship on the accuracy of the arrows before and during the pandemic which can be shown in Table 6 .

Table 6. Correlation Test for the accuracy of the

\begin{tabular}{llrrrc}
\hline & & N & Correlation & Sig. & Description \\
\hline Pair 1 & Pre_Ketepatan \& Post_Ketepatan & 9 & .898 & .001 & There is a difference \\
\hline
\end{tabular}

Based on table 6 known value of correlation of 0.709 with significant value 0,001 <probability of 0.05 , meaning that it can be concluded there is a relationship between variables Pre_ketepatan with Post_ketepatan variables. Then performed a different test using the $t$ test to analyze the significant differences in the two data which are contained in the Table 7 Paired Samples Test.

The results of table 7 show that there is a difference in the average difference in the target accuracy of PPLP Archery athletes in East Java before and during the Covid-19 Pandemic, the Sig value can be seen. amounted to $0.013<0.05$, which means that there is a significant difference in the accuracy of targeting for East Java PPLP Archery athletes before and during the Covid-19 Pandemic.

Table 7. Difference T test accuracy

\begin{tabular}{llcl}
\hline & & Sig. (2-tailed) & Description \\
\hline Pair 1 & Pre_Ketepatan -Post_Ketepatan & .013 & Significant \\
\hline
\end{tabular}

Based average calculation on the result of calculation Arm Muscle Endurance before Pandemic Covid-19 showed 302.3889 which means that the average value of the athlete's Arm 
Muscle Endurance category before the Covid-19 Pandemic was in a lower category than when the Covid-19 Pandemic was 280.7222, which means the average value of the Arm Muscle Endurance category for athletes in the Covid-19 Pandemic situation in smaller category. And after using the Paired T Test, the results showed that there was a significant difference between the accuracy of archery before the Covid-19 Pandemic and during the pandemic.

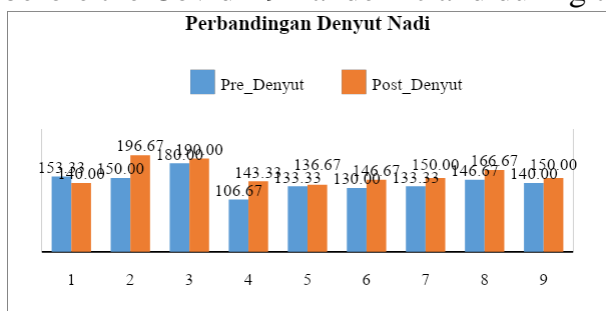

Fig. 5. Diagram of difference in average pulse before and during the Covid-19 pandemic

Results of mean Pulse Rate 141.4815 <Post_Deat 157.7778, which means that there is a difference in the average pulse rate between Pre_Pulse and Post_Pulse results. Then performed a different test using the $t$ test to analyze the significant differences in the two data which are found in table 10 Paired Samples Test.

In the results of table 8, a summary of the descriptive results of the two categories of data under study is obtained, namely the variables Before Covid-19 (Pre_Denyut) and the Pandemic Situation (Post_Denyut). For the Pre_Denyut value, an average of 141.4815 was obtained. Meanwhile, the Post_Denyut value obtained an average value of 157.7778. The number of PPLP Panahan athletes in East Java used as the research sample was 10 athletes.

Table 8 Descriptive test pulse

\begin{tabular}{|c|c|c|c|}
\hline & & Mean & Std. Deviation \\
\hline \multirow[t]{2}{*}{ Pair 1} & Pre_Denyut & 141.4815 & 20.00771 \\
\hline & Post_Denyut & 157.7778 & 21.92158 \\
\hline
\end{tabular}

In Table 8, it is also found that the value (Mean Paired Differences) is -16.29630 which shows the difference between the Pre_ Pulse average and the Post-Pulse average, namely $141.4815-157.7778=-16.29630$ and the difference between these differences.

Table 9 shows the correlation between the two Pre_Denyut variables and the Post_Denyut variable. Based on table 9, it is known that thevalue is Correlation 0.709 with a Sig. 0.057> 0.05 probability means that there is no relationship between the Pre_Denyut variable and the Post_Denyut variable.

Table 9 Correlation test

\begin{tabular}{llrrrc}
\hline & N & Correlation & Sig. & Description \\
\hline Pair 1 & Pre_Denyut \& Post_Denyut & 9 & .651 & .057 & There is a difference \\
\hline
\end{tabular}

In the results table 9 showed no relationship (correlation) difference in the average difference Pulse athletes Archery PPLP East Java before and Medium Pandemic Covid-19 can know the value of Sig. (2-tailed) of 0.057> 0.05, meaning that there is no difference in the 
average pulse rate of PPLP Archery athletes in East Java before and during the Covid-19 Pandemic.

Table 10 Differences t -test, pulse rate

\begin{tabular}{cccc}
\hline & & Sig. (2-tailed) & Information \\
\hline Pair 1 & Pre_Denyut - Post_Denyut & .024 & Significant The \\
\hline
\end{tabular}

Results of table 10 show that there is no mean difference in the accuracy of targeting athletes of PPLP Archery in East Java before and during the Covid-19 Pandemic, the Sig. is $0.024<0.05$, meaning that there is a significant difference in the Pulse of the East Java PPLP Archery athletes before and during the Covid-19 Pandemic.

Based on the calculation of the average data obtained the results of the Pulse calculation Before the Covid-19 Pandemic, the results were 141.4815, which means that the average score for the Pulse Rate category of athletes before the Covid-19 Pandemic was in a lower category and when the Covid-19 Pandemic (the average (mean) was obtained, 157.7778 was obtained which means the average value of the Pulse Rate category The Covid-19 Pandemic situation athletes are in a larger category. And after using the Paired T Test, the results showed that there was a significant difference between the pulse rate before the Covid-19 Pandemic and during the pandemic.

\section{Discussion}

This chapter will explain the results of the research that the researchers obtained from the push-up test, the scoring test and the athlete's pulse count test. The results of this research data were obtained from the research subjects ofathletes PPLP Panahanin East Java.

From the data retrieval process that begins before data collection, the researcher makes a coordination or agreement with the party to be studied so that data retrieval can run smoothly, this data collection is carried out when the athletes exercise together.

And then collect athletes and coaches in the same room to explain the research to be carried out and explain the research implementation rundown to the subject; The researcher prepared the writing equipment, stopwatch and score sheet then distributed to the athletes, After distributing the score sheet athlete's, the pulse rate before training was calculated with the same count which would be calculated through the stopwatch for 1 minute, After calculating the pulse before training then the athlete did atest. pushup for 1 minute with the same count via the stopwatch; Then the athlete performs atest scoring by shooting 36 arrows, in 6 series or encroachment, each series releases 6 arrows given 4 minutes of time; After 1 session is over the athlete counts the pulse of the exercise with the same count for 1 minute; After doing atest scoring for 2 sessions the athlete calculates the number of scores that have been obtained each with a predetermined distance, then collected to the researcher; Then the athlete counts the pulse after training with the same count that will be counted via the stopwatch for 1 minute; Then the researcher distributed the consumption to the subjects and thanked him.

Muscle Endurance is a person's ability to use his muscle mass to contract sustainably with a long load [13]. Muscle endurance is needed to maintain activities that are dominant in muscles. As with other components, muscle endurance is only needed in muscle activity and will gradually decrease with age [14] . 
Harsono [15] explains: "Muscle endurance is the ability of muscles to contract consecutively for a long time". Harsono [15] states that: " Strength endurance is the ability of the body's organs to overcome fatigue during activities that require strength for a long time. Achieving target accuracy in archery by doing systematic training, training using key words, practicing eye control and training to focus attention or other methods that will be provided by the trainer [3].

According to Hausswirth [16] defines that the pulse is an indicator to measure the intensity of exercise during physical activity. Recovery pulse rate is the number of pulse beats per minute measured after a 5 minute rest. This measurement is to measure how quickly a person's ability to recover after physical activity.

If an athlete has strong muscle power, accurate accuracy and a regular pulse, it will greatly affect his performance. Therefore an athlete must be able to maintain muscular endurance in the arms, archery accuracy and pulse both when training and competing with the right strategy. When an athlete is training they maintain the predominant activity of a group of muscles.

In athletes, the PPLP Archery condition of muscle endurance, accuracy and regularity of the pulse is very influential because it is one of the components to improve performance.athletes PPLP Archeryhave more intensive physical activity so the need for endurance training is needed.Requirements (Specific EnduranceSpecific Endurance) is endurance that works for a long, medium and short time that carries the characteristics of a sport [17] .

The results of the analysis of the mean Arm Muscle Endurance Before Covid-19 (Pre_Test) for PPLP Archery East Java athletes are in a higher category, which means that the average value of the Arm Muscle Endurance category for athletes in the Covid-19 Pandemic (Post_Test) situation is in the category smaller. As for the results of the difference test that has been carried out on Arm Muscle Endurance Before Covid-19 (Pre_Test) and the Covid-19 Pandemic (Post_Test) situation, $\mathrm{p}>0.05$, which means that there is no significant difference in the endurance of the athlete's arm muscles.

Previous research found that Dechline [18] there was a significant effect on bow training on the arm muscle endurance of novice archery athletes. This research is also supported by [19] which states that athletes should pay more attention and increase the endurance of arm muscle strength and eye coordination in order to produce better performance. The most easy and inexpensive way to maintain muscle endurance is to continue to train, because continuing to train consistently greatly affects the increase in strength and endurance of the arm muscles [20].

There are several ways to increase the strength and endurance of the athlete's arm muscles, one of which is by using a dumbbell tool as described by [21] with the results of the analysis of the effect of dumbbell thera training to increase archery accuracy and arm muscle endurance in athletes. archery in Banyumas district.

It can be concluded that an athlete who cannot maintain his muscular endurance, then the athlete cannot give his best performance, and cannot achieve maximum performance results. So an athlete must maintain his body so that he always has good muscle endurance in the period before Covid-19 with the Covid-19 pandemic situation. As stated by Muslim [22] and Gunawan [23] there is a significant relationship between muscle endurance and accuracy of archery shots which is the opposite if an athlete has weak arm muscle endurance, it will reduce the level of target accuracy or accuracy of archery shots.

The results of the analysis of the difference between the average (mean) value of Target Accuracy before Covid-19 (Pre_Accuracy) and the Covid-19 (Post_Ketalore) situation in East Java Archery PPLP athletes The results obtained are smaller categories, which means the average value of the athlete's Arm Muscle Endurance category in the Covid-19 Pandemic situation. As for the results of the difference test that has been carried out on Target Accuracy 
before Covid-19 (Pre_Cetness) and the Covid-19 (Post_Ketoritas) situation in PPLP Archery athletes in East Java $\mathrm{p}<0.05$, which means that there is a significant difference in the accuracy of the athlete's archery target.

Accuracy in archery can be achieved through systematic exercises, exercises using key words, practicing eye control and training to focus attention or other methods that will be given by the trainer [3] . Other research on the relationship between concentration levels and target accuracy has been conducted [24] . states that the duration of eye silence is much longer for accuracy than for inaccurate shots. The results suggest that the duration of focus decreases when the player is afraid, that focus reflects the efficiency of visual orientation. Therefore focused training is a useful intervention. Hardi \& Nurama [3] and Mukhtar et al [25] also support the results of this study with the results that the higher the level of concentration and accuracy of archery will produce good shots.

The relationship between training that is consistent with target accuracy is not only influenced by the level of focus or concentration of each athlete, but can also be influenced by psychology such as the athlete's panic level, self-confidence and also the intake of food and drink. This is supported by research [26] which states that the emergence of target panic or loss of control comes from themselves, which means that the athlete understands the panic of the target during competition or training in order to master emotions and better target accuracy. Another study conducted by [27] suggested the results of the analysis of the athlete's confidence level of $88.89 \%$, which means that the greater the athlete's confidence will affect the accuracy of archery targets.

It can be concluded that an athlete who cannot maintain his shooting accuracy, then the athlete cannot give his best performance, and cannot achieve maximum performance results. So an athlete must keep his body so that he always has good accuracy in the period before covid19 with the covid-19 pandemic situation.

The results of the analysis of the difference between thevalue averageof the pulse in the period before Covid-19 (Pre-Pulse) and the Covid-19 pandemic situation (Post_Pulse) are in a larger category, which means the average value of the Pulse rate category. athletes The situation of the Covid-19 pandemic is smaller than before the Covid-19 pandemic. As for the results of the difference test that has been done, the results obtained are $\mathrm{p}<0.05$, which means that there is a significant difference in the archery pulse of athletes.

Previous research has found that [28] stated that adrenergic hormone is a factor in the lack of physical exercise which causes the heart to predominantly increase the pulse rate. There are several ways to recover after strenuous activity so that the athlete's pulse returns to normal, namely by buying watermelons which are supported by [29] which states that giving watermelons after carrying out activities greatly affects pulse recovery in postkibra students of SMA Negri 4 Medan. In another study [30] consuming green coconut water before physical activity can affect pulse recovery in athletic athletes.

It can be concluded that an athlete who cannot maintain the regularity of his pulse, the athlete cannot give his best performance, and cannot achieve maximum performance results. So an athlete must maintain his body with regular exercise so that he always has a good pulse regularity in the period before covid-19 with the covid-19 pandemic situation.

\section{Conclusions and recommendations}

\subsection{Conclusion}


The results of the research from the title Comparison of Arm Muscle Endurance, Target Accuracy and Pulse of Training for East Java PPLP Archery Athletes in the Pre-Covid-19 Period With the Covid-19 Pandemic Situation it can be concluded that:

1. There is no significant difference in endurance Forearm muscles of athletes before Covid-19 (Pre_Otot) with the Covid-19 Pandemic (Post_Otot) situation with a significant level (Sig.> 0.05).

2. There is a significant difference in the target accuracy of athletes before Covid-19 (Pre_Cetness) with the Covid-19 Pandemic (Post_Cetness) with a significant level (Sig. $<0.05)$.

3. There is a significant difference in the pulse rate of athletes before Covid-19 (Pre_Denyut) with the Covid-19 Pandemic (Post_Teat) with a significant level (Sig. <0.05).

\subsection{Suggestion}

1. It is hoped that with the results like the above, the coaches pay more attention to the importance (always maintaining endurance of the arm muscles, accuracy of archery targets and regular pulse of the athletes) by regularly exercising and consuming good nutritious food in the pre-Covid-19 period with a pandemic situation. covid-19.

2. There needs to be a joint commitment in a team in order to get maximum results to really pay attention to the importance of arm muscle endurance, accuracy of archery targets and regularity of the pulse.

3. For athletes PPLP Archeryin East Java, they must know the need to maintain fitness for arm muscle endurance, archery target accuracy and pulse regularity in their respective bodies in order to avoid a decline inconditions goodbefore Covid-19 with the Covid-19 pandemic situation.

4. Forresearchers further, it is necessary to add variables or factors that function to get more accurate results about arm muscle endurance, archery target accuracy and pulse regularity.

\section{Acknowledgment}

The authors would like to thank the Sports Coaching Education Study Program, Faculty of Sport Science, Universitas Negeri Surabaya for providing funding for this research.

\section{References}

[1] Cambridge U. Archery. https://dictionary.cambridge.org/dictionary/englsh/archery. di akses 24 Juli 2020. 2018.

[2] Munawar, Hidayatulloh MF, Kristiyanto A. Prediksi Prestasi Ronde Nasional Berdasarkan Daya Tahan Otot Lengan, Ketajaman Penglihatan, dan Kecemasan pada Atlet PPLP Panahan Jawa Tengah. Sport Sci. 2003;1(1).

[3] Hardi VJ, Nurama D. Hubungan Tingkat Konsentrasi Terhadap Ketepatan Memanah. J olahraga. 2019; vol 5(2).

[4] Prasetyo Y. Pengaruh latihan Deep Breathing Terhadap Peningkatan Hasil Skor Total Jarak Panahan Ronde Nasional Pada UKM Panahan UNY. J olahraga prestasi. 2016;vol.12(1). 
[5] Rizal M. . Kontribusi Kekuatan Otot Bahu, Kekuatan Otot Lengan, Kekuatan Otot Perut, dan Konsentrasi Terhadap Tembakan Pemanah Jarak 50 Meter Ronde Recurve. Prestasi Olahraga. $2018 ; 1$.

[6] Susanto. Pengaruh Latihan Sirkuit Terhadap Peningkatan Kebugaran Jasmani dan Ketepatan Membidik Panahan pada Anak Usia Dini. TA’ALLUM. 2015;Vol.03(02).

[7] Akbar SDP, Marisa D, Husairi A. Perbedaan Tekanan Darah dan Denyut Nadi Sebelum dan Sesudah Latihan Fisik Intensitas Sedang Pada Pemain Futsal. Homeostatis. 2019; vol 2(3):301-406.

[8] Ashadi K, Andriana LM, Pramono A. Pola aktivitas olahraga sebelum dan selama masa pandemi covid-19 pada mahasiswa fakultas olahraga dan fakultas non-olahraga Sports activity patterns before and during covid-19 pandemic in students of the sports faculty and non-sports faculty PENDAHULUAN C. 2020;6(3):713-28.

[9] Lestari YTW, Ashadi K. PERBANDINGAN DENYUT NADI, STATUS HIDRASI, DAN JUMLAH KALORI DALAM AKTIVITAS SUB MAKSIMAL DENGAN MENGGUNAKAN MUSIK DAN TANPA MUSIK PADA MAHASISWA FIO UNESA. J prestasi olahraga. 2019; vol 2(3).

[10] Bashri A, Marsudi I, Aji RNB, Ashadi K, Mukhzamilah. Feasibility of Media for Healthy Living Patterns for Elderly Through Herbal Beverages to Prevent Covid-19 Transmission. 2020;491(Ijcah):1078-82.

[11] Mintarto E, Pramono BA, Mustar YS, Ashadi K, Purnomo M. Need-Assessment of Physical Activity as an Effort to Increase Immunity During the Covid-19 Pandemic. 2020;491(Ijcah):1149-54.

[12] Ashadi K, Marsudi I, Rochmania A, Jayadi I, Siantoro WG. Students Exercise Patterns During the COVID-19 Pandemic. 2020;491(Ijcah):1230-7.

[13] Ninzar K. Tingkat Daya Tahan Aerobik (Vo2 Max) Pada Anggota Tim Futsal Siba Semarang. eJournal mitra Pendidik. 2018;vol 2(08):738-49.

[14] Nasrulloh A. Pengaruh Latihan Circuit Weight Training Terhadap Kekuatan dan Daya Tahan Otot. medikora. 2012; vol 3(2).

[15] Harsono M. Coaching dan aspek-aspek psikologis dalam coaching. Direktorat Jendral Pendidik Tinggi. 1998;

[16] Hausswirth C. Recovery For Performance In Sport. 2013.

[17] Sajoto M. Pembinaan Kondisi Fisik Dalam Olahraga. Semarang. Dahara Price. 1988;

[18] Decheline G, Widowati A, Maryani NTS, Ali M, Aqobah QJ, Barikah A. The Effect of Bow Training on the Endurance of the Arm Muscles of the Beginner Archery at Kobar Club , Jambi City. 2020;

[19] Astuti Y. The Power Contribution of Arm Muscle Strenght and Eyes-Hand Coordination to Voleyball Set Up Passing Skill. J Pendidian Indones. 2018; 6(2):168-71.

[20] Surahman HB, Kanca IN, Tisna GD. Pengaruh Pelatihan Bermain Bulutangkis Overhead Clear Drill Terhadap Kekuatan Dan Daya Tahan Otot Lengan. J Ilmu Keolahragaan Undiksha. 2018; 6(3):0-7.

[21] Teofa B, Wibafied P, Yachsie B, Kunci K, Band D-T, Tahan D, et al. Effects of Dumbbell-Thera Band Exercise Towards the Arm Muscle Endurance and Archery Accuracy in Archery Athletes. Medikora. 2019; XVIII(2):79-85.

[22] Muslim. Hubungan Daya Tahan Otot Lengan Terhadap Hasil Tembakan 30 M Pada Atlet Panahan PPLP Dispora Riau Tahun 2016. J Online Mhs Fak Kegur dan Ilmu Pendidik Univ Riau. 2016;vol 3(10):1-10.

[23] Gunawan G. Pengaruh Latihan Kekuatan Otot Lengan Terhadap Akurasi Tembakan Panahan Berbasis Aplikasi. J Sport Athl Teach Recreat Interdiscip Anal. 2020; 3(2):12-9.

[24] Behan M, Wilson M. State Anxietyand Visual Attention: The Role Of The Quite Eye Period in Aiming to a Far Target. J Sports Sci. 2008;vol 26(2):207-15.

[25] Mukhtar, Abdurrahman, Ifwandi. Hubungan Tingkat Konsentrasi dengan Ketepatan Memanah pada Atlet Panahan Aceh Achery School Binaan Dispora Kabupaten Bireuen 2015. J Ilm Mhs Pendidik Jasm Kesehat dan rekreasi. 2017; vol 3(1).

[26] Prior EE, Coates JK. Archers' experinces of Target Panic: an Interpretetative Phenomenological analysis. Qual Res Sport Exerc Heal. 2020;vol 12(2)(224-241).

[27] Hardi VJ, Budiman A, Riyadi I. Tingkat percaya diri atlet panahan Cimahi Mandiri Archery Club. JPOE. 2020; vol 2(2):221-7. 
[28] Akbar SDP, Marisa D, Husairi A. Perbedaan Tekanan Darah dan Denyut Nadi Sebelum dan Sesudah Latihan Fisik Intensitas Sedang Pada Pemain Futsal. Homeostatis. 2020;vol 2(3):401-6.

[29] Lubis RF, Siregar NS. Pengaruh Pemberian Semangka Terhadap Denyut Nadi Pemulihan Setelah Melakukan Aktivitas Fisik. Sains Olahraga J Ilm Ilmu Keolahragaan. 2017;1(1):1-10.

[30] Yusuf J, Muthoharoh A, Setyawan MGM. Pengaruh Air Kelapa Hijau (Cocos Nucifera) Sebelum Aktifitas Fisik Aerobik Terhadap Pemulihan Denyut Nadi Pada Atlet Atletik. Jendela Olahraga. 2020;5(2):79-88. 